\title{
Introducing Maker-Inspired Technology in the Finnish Craft Subject - A Case Study from One School
}

\author{
Rasmus Borg, Mia Porko-Hudd and Juha Hartvik
}

In the last two decades, the use of technology in Finnish basic education has developed rapidly. The combination of digital and analogue resources is emphasized especially in the maker movement to reduce abstraction in digital equipment. Craft as a learning subject has substantive conditions for offering pupils instruction in both traditional analogue and current digital working methods within the subject area. The purpose of this study was to examine what kind of knowledge and skill development are expressed when three types of maker-inspired technologies consisting of $3 D$ modelling, $3 D$ printing and e-textiles, are integrated into a lesson sequence in craft in Grade 7 in a Finnish basic education school. The study was conducted as an action research cycle consisting of seven lessons within a craft sequence. The data collection method was a questionnaire. The study shows the development of pupils' self-reported knowledge and skills as well as their attitudes towards the technological contents of the lesson sequence.

Keywords: craft, sloyd, maker movement, basic education

\section{Introduction and background}

Finland's over 150-year tradition of the craft school subject has similarities to contemporary maker education. Since the 1970s, research has developed so that, today, there are craft-related science disciplines at four universities in Finland. These disciplines form the basis for relating to and being influenced by, for example, the form of activity and content of technology and maker education. The school subject has developed over time both in terms of content and pedagogical ideals. (Porko-Hudd, Pöllänen \& Lindfors, 2018). The current research focuses on the pupil perspective at a school that introduces more maker-inspired content in the craft subject. In this way, a nuanced picture is obtained of how this can develop the traditional content of the craft subject. The purpose of this study, thus, was to examine what kind of knowledge and skill development are expressed when three types of makerinspired technologies consisting of 3D modelling, 3D printing and e-textiles, are integrated into a lesson sequence in craft in Grade 7 in a Finnish basic education school. The following two research questions were formulated for the study: What are the similarities and differences in the infrastructure between the Finnish craft school subject and contemporary maker education? What can be seen in pupils' selfreported technology-related knowledge development, and how do pupils relate to this new content in craft?

The curriculum for basic education in Finland (National Board of Education, 2014) highlights the need for digital competence. This has led to discussions about the benefit of pupils learning the basics of programming (Godhe, Lilja \& Selwyn, 2019; Räisänen, 2017). There is a common belief that gaining early insight into the possibilities of, for example, 3D modelling and programming could inspire pupils to make future technology-related career choices. The use of digital aids in contemporary school contexts is needed to gain knowledge of good practices and outcomes. According to Dufva (2017, p. 135 ) when something is being crafted by hand by utilizing digital tools, there is an opportunity to reduce 
the abstraction of the digital and thereby increase the understanding and ability to interact with digital technology. Instead of only acting as a consumer of digital products, one can apply digital technology in crafting and, thus, incorporate previous knowledge with new opportunities.

Rosenfeld, Halverson and Sheridan (2014, pp. 499-500) and Hsu, Baldwin and Ching (2017) describe the increasingly common practice in the United States of reshaping schools' learning environments in accordance with spaces within the maker movement. In Finland, however, there already exists a rich tradition of making things within the educational craft subject. Since the 1970s, there has been an expectation and opportunity to include electronics and other technology-related content in addition to wood, metal and textile work. Despite this, the maker workshop concept can bring ideas and procedures from which the subject could benefit. In the Swedish context, it is deemed necessary to establish creative environments where pupils can combine digital technology with traditional and manual skills (Heath, 2017, pp. 171-172). According to Heath (2017), the schools' craft spaces need to be adapted to incorporate new equipment and materials. However, the ways in which stakeholders and teachers interpret this possibility vary greatly.

In Finland, there are already good structural opportunities to include new content areas in the current craft subject. The objectives for learning environments and working methods in craft in Grades 1-9 emphasize appropriate and safe premises. Tools, machines, devices and materials constitute elements that support and enable learning. Further, wide usage of information and communication technology supports pupils' work and planning during different phases of the craft process (National Board of Education, 2014). Uljas and Wendelius (2018) align their interest to factors that should be considered when developing learning environments in craft. Their study shows that craft teachers demand spaces for the rich and wide range of craft techniques and a common planning space. In addition, the need for new technological equipment in the form of, for example, laser cutters and 3D printers is also highlighted (Jaatinen, 2017). Teachers are central actors when the development of a subject is sought. Sundqvist's (2006) case study follows how two teachers planned and implemented teaching in a project focused on how 3D printing, programming and textile techniques can be implemented in a craft sequence for pupils aged 9-12 years. The results show that challenges with the technical equipment, application of the program, design of the area of interest and concrete 3D printing were among the conditions most often mentioned when the teachers reflected on the completed teaching.

Long before the establishment of the maker movement and without influences of the maker culture, schools in Finland had their own exemplary maker workshop. Although there already exist a strong tradition and a wide range of equipment in the craft school subject, it is necessary to relate to maker education when evaluating and developing the contemporary craft subject. For example, Kafai et al. (2014, p. 547) state that e-textiles have a positive impact on inclusion and gender equality, which raises the question of whether this content could be made more widely available in the craft subject. In a manifesto, Hatch (2014, pp. 24-25) presents an inventory of equipment that he believes should be in a maker workshop to meet the contemporary demands of manufacturing. Hatch points out that the tools needed for making have never been as cheap or as easy to use and powerful as they are today. Tapaninen (2002) presents a similar list of equipment recommendations for the teaching of craft in basic education in Finland with an emphasis on technical craft, excluding textile craft. To identify similarities and differences between the craft subject and maker education, the two lists have been processed and compiled in Table 1. 
Table 1: Comparison between Hatch's (2014, pp. 24-26) list of what a well-equipped maker's workshop should contain and Tapaninen's (2002, pp. 40-44) planning guide for primary school craft spaces (technical craft).

\begin{tabular}{|c|c|c|c|}
\hline $\begin{array}{l}\text { Maker workshop equipment } \\
\text { recommendation (Hatch, 2014, pp. } \\
24-26)\end{array}$ & $\begin{array}{c}\text { Grades } \\
1-6\end{array}$ & $\begin{array}{c}\text { Grades } \\
7-9\end{array}$ & $\begin{array}{c}\text { Maker equipment missing from Tapaninen's (2002) } \\
\text { guide compared to Hatch's list }\end{array}$ \\
\hline $\begin{array}{l}\text { Plastic processing machinery } \\
\text { ( } 3 \text { types of equipment mentioned) }\end{array}$ & 1 of 3 & 2 of 3 & $\begin{array}{l}\text { Plastic moulding equipment } \\
\text { Vacuum press in Grades } 1-6\end{array}$ \\
\hline $\begin{array}{l}\text { Textile craft machines } \\
\text { ( } 3 \text { types of equipment mentioned) }\end{array}$ & 0 of 3 & 0 of 3 & $\begin{array}{l}\text { The guide only describes equipment related to } \\
\text { technical craft. Sewing machines and overlock } \\
\text { machines are found in textile craft studios. }\end{array}$ \\
\hline $\begin{array}{l}\text { Machines for wood working } \\
\text { (9 types of equipment mentioned) }\end{array}$ & 8 of 9 & 9 of 9 & $\begin{array}{l}\text { The only thing the guide does not list for Grades } 1- \\
6 \text { is a CNC cutter. }\end{array}$ \\
\hline $\begin{array}{l}\text { Sheet metal working } \\
\text { machines } \\
\text { ( } 6 \text { types of equipment mentioned) }\end{array}$ & 1 of 6 & 3 of 6 & $\begin{array}{l}\text { Hole punch and corner punch for sheet metal, } \\
\text { "English wheel" and pneumatic air hammer }\end{array}$ \\
\hline $\begin{array}{l}\text { Metal processing machinery } \\
\text { ( } 5 \text { types of equipment mentioned) }\end{array}$ & 1 of 5 & 4 of 5 & $\begin{array}{l}\text { Vertical metal band saw } \\
\text { Metal grinding machine in Grades } 7-9 \\
\text { Mitre and band saw for metal and sandblasting } \\
\text { cabinet in Grades } 1-6\end{array}$ \\
\hline $\begin{array}{l}\text { Welding and cutting equipment } \\
\text { ( } 4 \text { types of equipment mentioned) }\end{array}$ & 0 of 4 & 2 of 4 & $\begin{array}{l}\text { Plasma cutters and TIG welders are missing, } \\
\text { although gas cutters are usually used and TIG } \\
\text { welders are found in some schools. } \\
\text { Tapaninen's guide includes point and MIG welding. }\end{array}$ \\
\hline $\begin{array}{l}\text { Metal lathes and cutters } \\
\text { ( } 3 \text { types of equipment mentioned) }\end{array}$ & 0 of 3 & 3 of 3 & $\begin{array}{l}\text { According to Tapaninen, various metal lathes and } \\
\text { cutters belong to Grades 7-9. }\end{array}$ \\
\hline $\begin{array}{l}\text { Computer-controlled machines } \\
\text { and associated equipment } \\
\text { (11 types of equipment } \\
\text { mentioned) }\end{array}$ & 1 of 11 & 1 of 11 & $\begin{array}{l}\text { Tapaninen's guide is deficient in information } \\
\text { technology and associated equipment as well as } \\
\text { computer-controlled tools. Computers are listed in } \\
\text { the form of "IT equipment". These include laser } \\
\text { cutters, 3D printers, 3D scanners, computer- } \\
\text { controlled vinyl cutters, water cutters, Wi-Fi, } \\
\text { computers for design purposes and various } \\
\text { software licences. }\end{array}$ \\
\hline $\begin{array}{l}\text { Other equipment } \\
\text { (12 types of equipment } \\
\text { mentioned) }\end{array}$ & 4 of 12 & 4 of 12 & $\begin{array}{l}\text { Much in this category is not appropriate in craft } \\
\text { teaching. The equipment that Tapaninen lists } \\
\text { includes compressed air systems and tools, } \\
\text { electronic testing and soldering equipment, and } \\
\text { storage areas. In contrast, for example, a granite } \\
\text { slab with digital scales, rental studios, meeting } \\
\text { rooms, retail and free coffee and popcorn do not } \\
\text { add value in craft teaching. }\end{array}$ \\
\hline
\end{tabular}

When comparing the two lists to find similarities and differences in the infrastructure between the Finnish craft school subject and contemporary maker education, it becomes obvious that Hatch's list contains some equipment not mentioned by Tapaninen. It also becomes clear that several of the equipment categories correspond well. The differences can also be partly explained by the fact that when 
Tapaninen (2002) compiled this guide, for example, programmable electronics and equipment for 3D printing were not available to the extent that they now exist. The comparison numbers in the table show how much of the crafting equipment in the planning guide is highlighted in the maker workshop recommendations. Especially for Grades 7-9, the equipment recommendations are very well matched, except for areas connected to computer-controlled equipment. It is worth pointing out that the target group for Hatch's maker workshops is adults who use maker workshops for the automation that the equipment provides. Such equipment, however, may be less suitable for pupils in Grades 1-6 (aged 712 years).

\section{Method}

This study is part of the project "3D writes the future" funded by the National Board of Education. The overall aim of the project is to integrate augmented reality, programming, 3D modelling and 3D printing in the craft subject. The current study was inspired by action research. Rönnerman (2012, p. 26) describes action research as a spiral comprising four different steps: plan - act - observe - reflect. Development and change are the most important purposes of action research. Although action research usually relies on experiences and leads to new reflected cycles of action, the circumstances did not allow for more than one cycle in this project.

A craft group of 13 pupils in Grade 7 was established. The period for the learning sequence consisted of seven 90-minute lessons. A newly inaugurated maker workshop served as the teaching space. The workshop was interpreted as a neutral place where pupils' prejudices and experiences of previous craft spaces would not affect their attitudes to the craft project at hand. E-textiles, 3D modelling and 3D printing were chosen as the technological areas of the project "See me!" The learning task was to create a product for better visibility. The learning aims were dare to test new things, be creative, have your own ideas, take responsibility for your own work, apply previous skills and knowledge, use the instructions on your own, get a wider understanding of $3 D$ creation and arouse interest in programming and provide new opportunities.

Surveys are effective when one wants to be able to generalize results or see trends (Stukát, 2011, pp. 47-49). The survey was made as an informed controlled survey that was personal and distributed by the researcher on site (Hirsjärvi, Remes \& Sajavaara, 2001, pp. 183-184). The survey was intended to reveal the pupils' self-reported learning within the subject areas in the learning sequence. The teaching content during the lessons corresponded with statements of technological aspects that the pupils were asked to report in the survey. The surveys were summarized in Google Spreadsheets based on the automatic compilation downloaded from Google Forms. The results consisted of pupils' responses to the various statements. In the analysis phase, each answer was given a number: $1=$ not at all, $2=$ to some extent, 3 $=$ quite good and $4=y e s$, meaning that one can fully complete the actual task. The numbers were used to calculate an average of the pupils' answers per statement for each lesson. With the help of means, it was possible to illustrate the pupils' self-reported knowledge development in different subject areas. For answers to the open questions in the last section of the survey, each pupil was given a number (P1, P2, etc.), which allowed a follow-up of the answers.

The pupils were informed about the purpose of the research and their guardians approved their participation in the study. The pupils were also guaranteed anonymity and informed of the opportunity to withdraw their participation in the study at any time. All survey responses have been managed in a password-protected database to ensure that only the researcher has access to them. 


\section{Results}

Perceived knowledge development in the technology areas is illustrated in Figures 1-4, and the pupils' interest in, and reflections on, future benefits of the areas are illustrated in Figures 5-6. Each aspect of the pupils' knowledge in Figures 1-4 is represented by a curve of a specific colour. The curve illustrates how high the class mean was for each lesson within the sequence. If the mean value of a statement (between 1 and 4) at the end of the sequence is higher than at the beginning, it indicates that the pupils progressed in terms of self-reported knowledge.

Figures 1 and 2 illustrate 12 aspects of knowledge development within the use of the Tinkercad 3D modelling program. For most of the six aspects in Figure 1, no remarkable development took place, except that the pupils reported that they had become better at using different camera angles and the hole function in the program. At the same time, one can see that the pupils' reported knowledge remained at a relatively high level throughout the sequence. The six aspects focus on basic skills in Tinkercad.

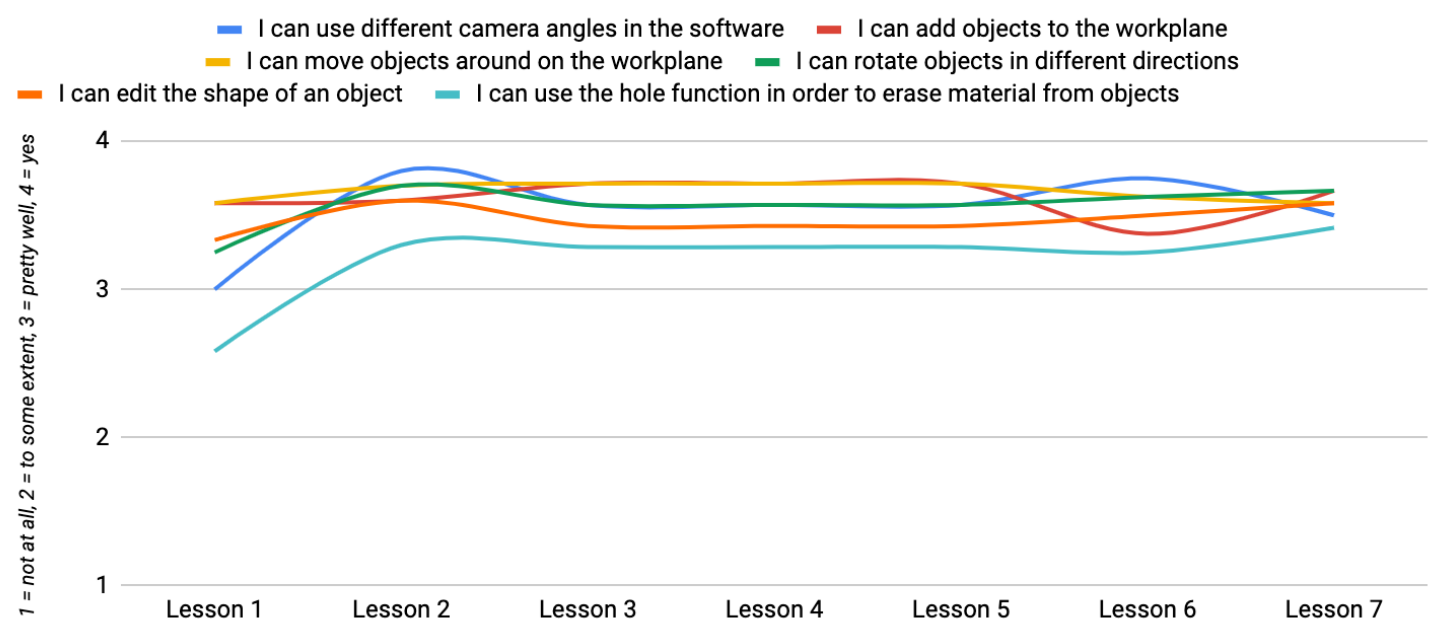

Figure 1: Knowledge development within the use of basic Tinkercad functions.

The pupils' knowledge development regarding the six other aspects of Tinkercad, illustrated in Figure 2, shows remarkable development from lesson 1 to lesson 3 and a stagnation and slight decline in some areas towards the end of the lesson sequence. These aspects of Tinkercad are more advanced, which can explain the increasing knowledge development during lessons 1 to 3 .

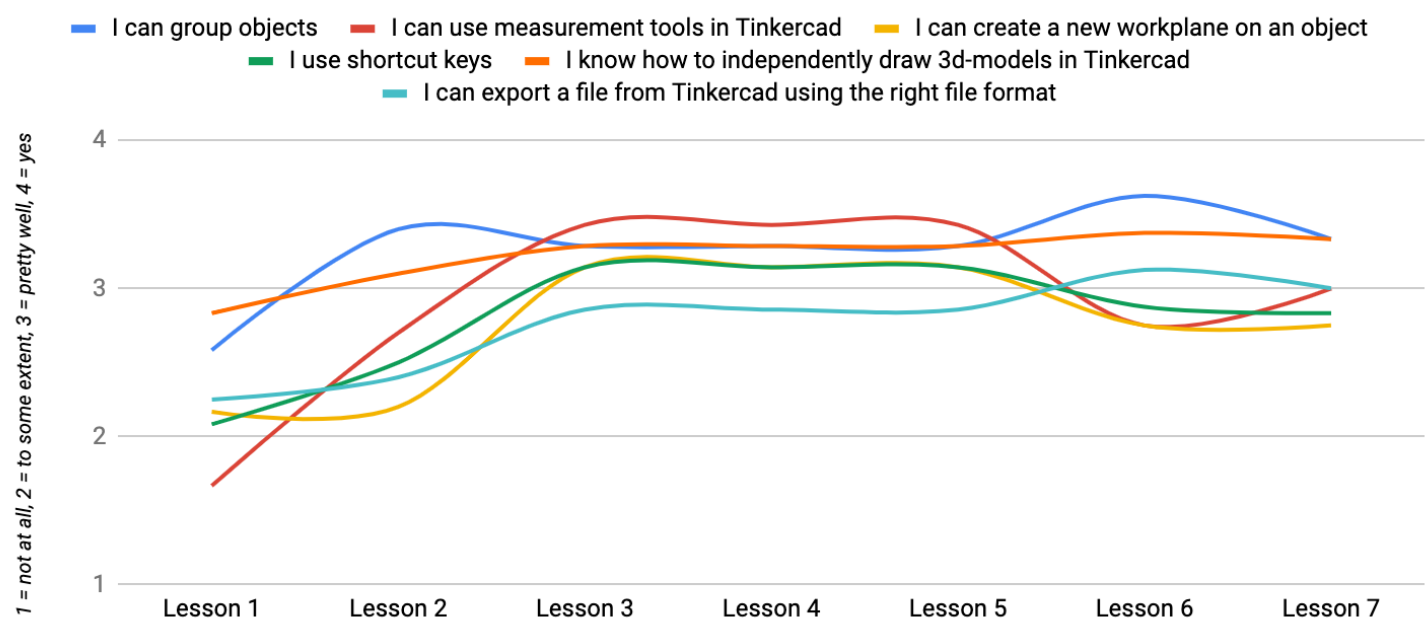


Figure 2: Knowledge development within the use of more advanced Tinkercad functions.

Figures 3 and 4 illustrate 10 distinct aspects of the pupils' development in e-textiles, which was introduced during the second lesson. Despite this early introduction, few pupils started working with etextiles during the first three lessons. Figure 3 shows five aspects where the pupils' skills developed, especially regarding to how to physically connect LED lamps and other components to the LilyTiny circuit. It is noteworthy that the values of all aspects decline towards the end of the sequence. This may be due to the feeling of lack of time; however, this was not studied in depth.

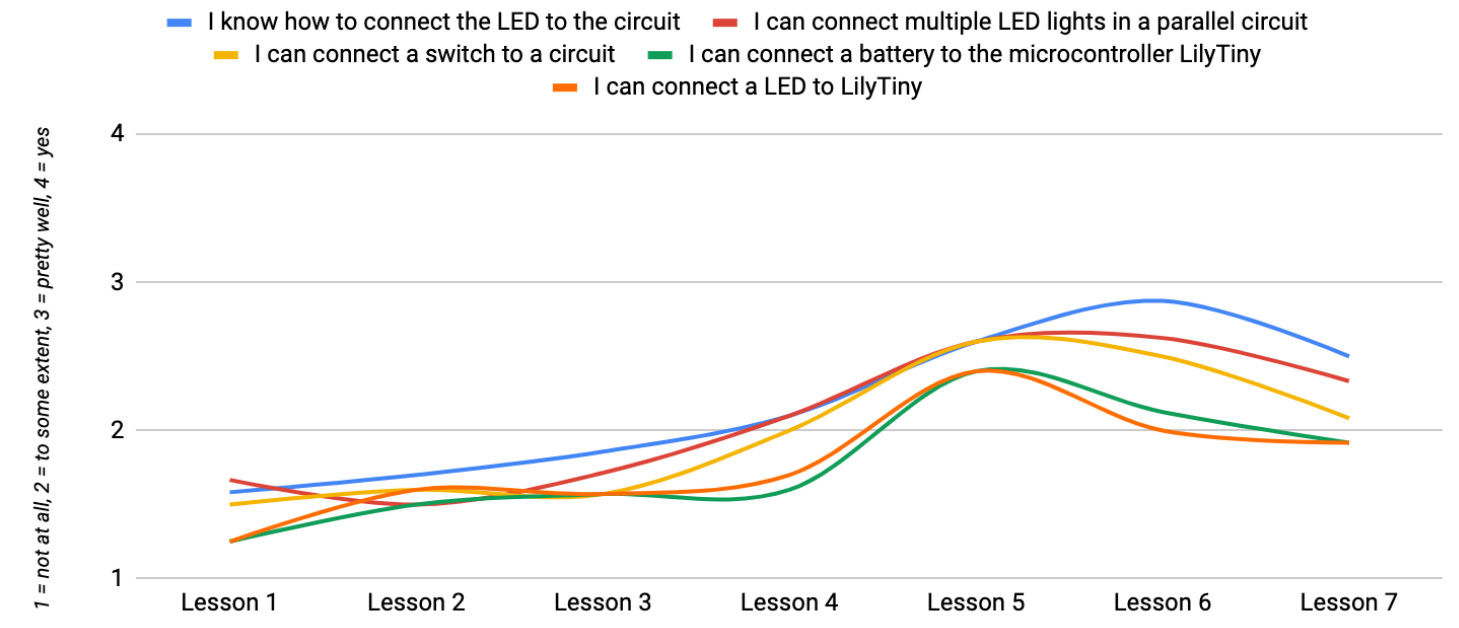

Figure 3: Knowledge development regarding connecting components in LilyTiny.

Figure 4 visualizes statements related to five aspects of programming and troubleshooting LilyTiny. The two aspects regarding programming (red and blue curves) stand out with lower averages. As few pupils had time to test programming, the group's reported knowledge within the area remained at a low level.

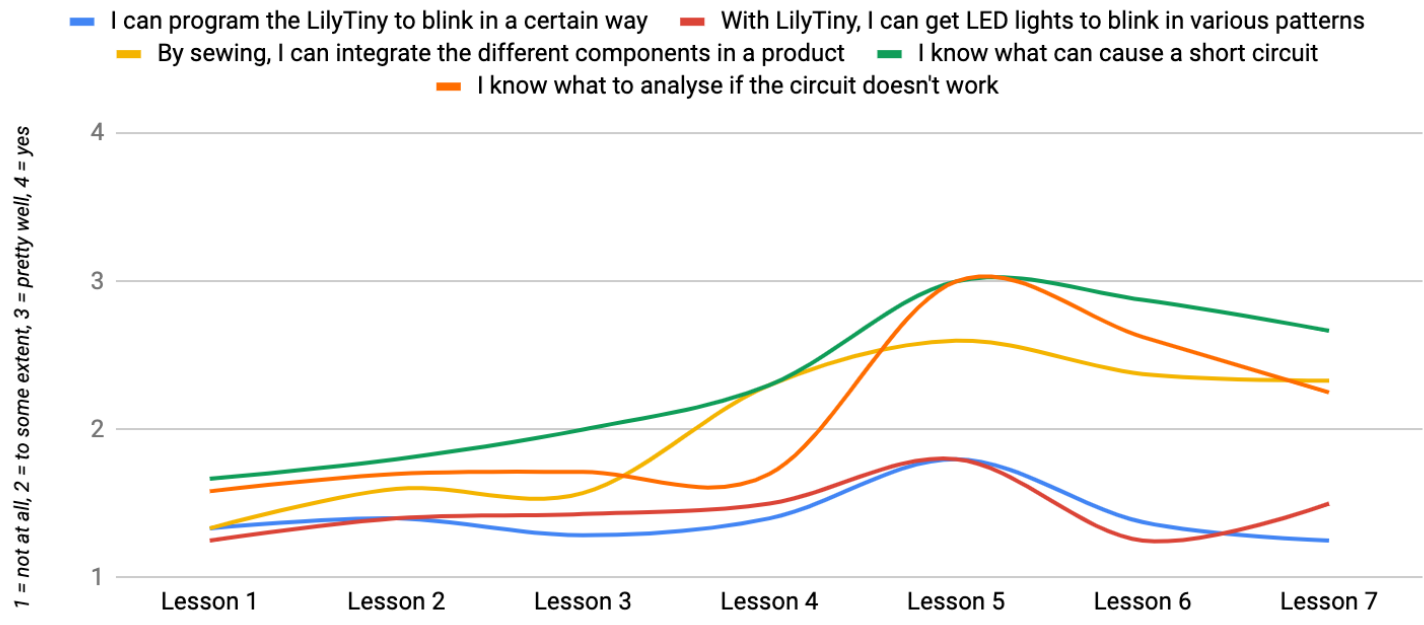

Figure 4: Knowledge development regarding programming, troubleshooting, and sewing LilyTiny.

Several pupils reported gaining a greater understanding of troubleshooting and how to avoid short circuits. They also became better at sewing components into their craft products. However, the lack of time may have contributed to the fact that some pupils reported negative experiences of working with e-textiles. The components are small and there is an imminent risk of short-circuiting if you choose to sew several LEDs to your project. The pupils' opinions were also divided as to whether e-textiles should be included in craft teaching. Yet the majority considered e-textiles a positive addition to the subject. 
The pupils were also given the opportunity to describe their levels of interest in the various subject technology areas (Figure 5).

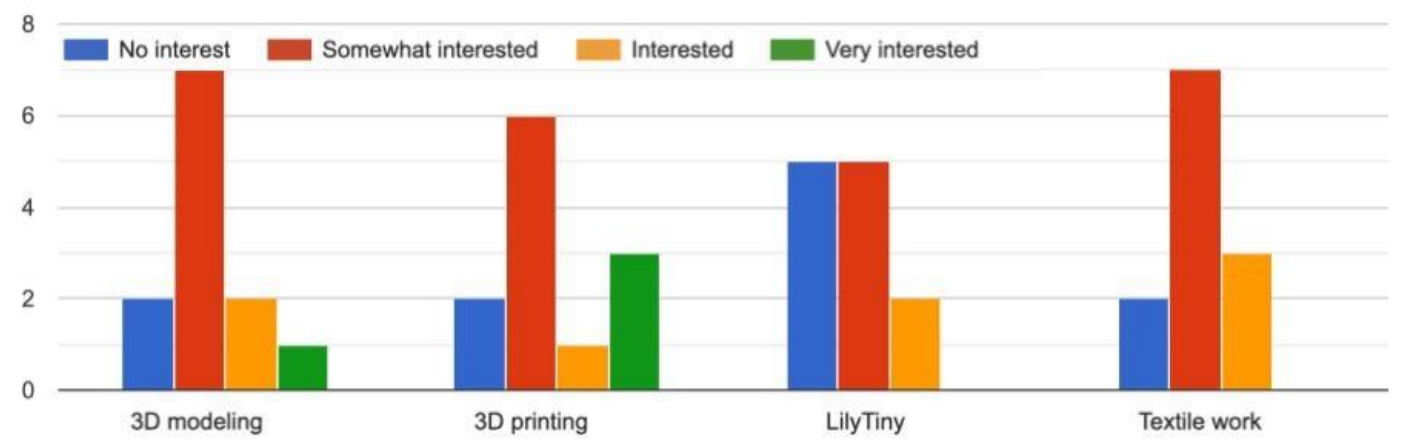

Figure 5: Pupils' interest in different technology areas.

As can be seen in Figure 5, most pupils found the different areas reasonably interesting. There were also pupils who were very interested in 3D modelling and 3D printing. However, there were no such positive statements regarding e-textiles.

The pupils also reflected on potential future benefits of the various subject areas (Figure 6).

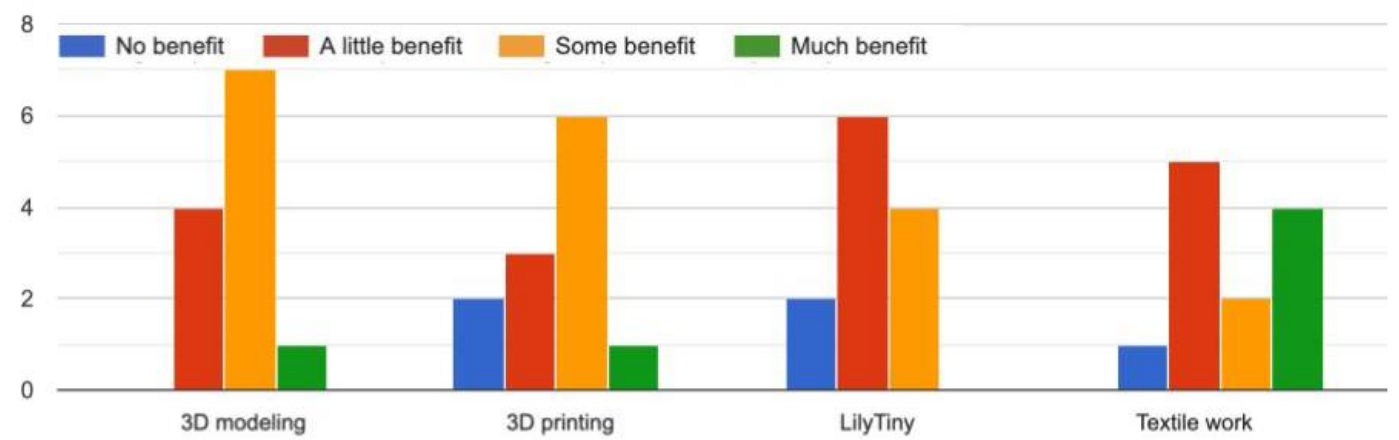

Figure 6: Pupils' reflections on future benefits of different technology areas.

The results show that pupils thought the benefits would be the greatest regarding knowledge in 3D modelling, 3D printing and textile work. When looking at no benefit and a little benefit, one can see that LilyTiny seems to be the area that the pupils saw as the least beneficial. Overall, Figure 6 shows that the same content can be perceived very differently by pupils that have taken part in the same teaching.

\section{Discussion}

As we initially stated, the Finnish education system has good opportunities to benefit students' learning through school subjects based on the production of artefacts. There is an established tradition and an infrastructure that provides good opportunities for further development (Jaatinen, 2017; Uljas \& Wendelius, 2018). The fact that new forms of activity, such as maker education, are emerging provides a good basis for reflection, as the familiar must be preserved and further developed. Regarding the study's first research question - What are the similarities and differences in the infrastructure between the Finnish craft school subject and contemporary maker education - we can state that the craft equipment available in compulsory school and the equipment described in maker education are largely similar (see Hatch, 2014; Tapaninen, 2002). At the same time, the maker movement provides inspiration for further development of the craft subject's content and working methods. In a situation where new content is considered or included in the subject, there must also be a discussion focused on what of the existing content can be omitted. Teachers need arenas where this can be discussed and implemented in order for it to be consolidated at the local level. 
When considering the second research question - What can be seen in pupils' self-reported technologyrelated knowledge development, and how do pupils relate to this new content in craft-3D modelling is a feature that the pupils appreciated. The fact that many pupils were previously familiar with the program fostered the conditions for their enthusiasm in the beginning. Although the pupils' average development in 3D modelling was most exponential from lessons 1 to 2 , they made great progress also in some of the sub-areas studied. With a few exceptions, pupils' response in connection to 3D modelling was positive. Several of them felt that they would benefit from 3D modelling in the future. 3D printing was more challenging for both pupils and teachers. A contributing cause could be the various elements that the technology comprises in combination with the time it took to print the articles. Few pupils had previous experience in 3D printing and the study's results show that pupils advanced in the use of both slicing programs and 3D printing. Unlike familiar craft processes, 3D printing is time-consuming during the printing process and the risk of failure is high. These factors demand the pupil's attention in other ways than traditional craft processes, in turn, presupposing a different approach to work in and out of class time for both teachers and pupils. Figures 1-4 show a certain stress effect caused by lack of time in lesson 7. The time-consuming processes in connection to, for example, 3D printing do not fully fit into the limited time and structured lesson plan that the school has.

Many of the pupils did not get started with the work in e-textiles during the sequence. Even though some pupils were negatively attuned to the area, others saw the benefit of, among other things, developing knowledge of electronics via e-textiles. E-textiles work well but, like 3D printing, are time-consuming. To fully make use of the iterative process of testing and developing the programming features, it is important to critically reflect on the amount of content and available time in a learning sequence. In the current study, it can be seen that "less is more" in terms of the amount of content.

Although it is still relevant to learn how to make things from wood, metal, yarn and fabric, the maker movement has broadened the area. It is now possible to have computers and machines do part of the work. Although computers do part of the work in 3D printing, 3D modelling and e-textiles, it is still individuals who create the design and build everything together into a functioning whole. In other words, the use of computer-controlled equipment does not exclude manual work. Just as in crafting, it is about the interaction between thought and hand; only the tools are different.

\section{References}

Borg, R. (2019). Digi-manuell slöjd. En elevgrupps och lärares möte med 3D-modellering, 3D-skrivning och etextilier i slöjdämnet. [Digi-manual craft. A student group and teacher's meeting with 3D modelling, 3D writing and e-textiles in the craft subject]. Master's thesis in sloyd education. Vasa: Åbo Akademi. Retrieved from https://www.doria.fi/bitstream/handle/10024/169540/borg rasmus.pdf?sequence=2\&isAllowed=y

Dufva, T. (2017). Maker movement. Creating knowledge through basic intention. Techne Series - Research in Sloyd Education and Craft Science A, 24(2), 129-141. Retrieved from https://journals.hioa.no/index.php/techneA/article/view/1910

Godhe, A-L., Lilja, P. \& Selwyn, N. (2019). Making sense of making: critical issues in the integration of maker education into schools. Technology, Pedagogy and Education, 28:3, 317-328. https://doi.org/10.1080/1475939X.2019.1610040

Hatch, M. (2014). The maker movement manifesto: rules for innovation in the new world of crafters, hackers, and tinkerers. New York: McGraw-Hill Education.

Heath, C. (2017). Makerkultur - huvudets och handens arbete. [Maker culture - work of the head and hand]. In M. Rylander Lundström (Ed.), Slöjd i en digital skola. [Craft in a digital school]. (pp. 157-174). Stockholm: Lärarförlaget.

Hirsjärvi, S., Remes, P. \& Sajavaara, P. (2001). Tutki ja kirjoita. [Investigate and write]. Helsingfors: Tammi.

Hsu, Y-C., Baldwin, S. \& Ching, Y-H. (2017). Learning through making and maker education. TechTrends, 61, 589-594. https://doi.org/10.1007/s11528-017-0172-6 
Jaatinen, J. (2017). Käsityön monipuoliset oppimisympäristöt. [Diverse learning environments for crafts.] Retrieved from https://www.edu.fi/perusopetus/kasityo/ops2016_tukimateriaalit/kasityon_monipuoliset_oppimisymparistot

Kafai, Y. B., Fields, D. A. \& Searle, K. (2014). Electronic textiles as disruptive designs: supporting and challenging maker activities in schools. Harvard Educational Review, 84(4), 532-556. https://doi.org/10.17763/haer.84.4.46m7372370214783

National Board of Education, 2014. (2014). Grunderna för läroplanen för den grundläggande utbildningen. [The basics of the curriculum for basic education.] Retrieved from http://www.oph.fi/lp2016/grunderna_for_laroplanen

Porko-Hudd, M., Pöllänen, S., \& Lindfors, E. (2018). Common and holistic crafts education in Finland. Techne Series - Research in Sloyd Education and Craft Science A, 25(3), 26-38. Retrieved from https://journals.oslomet.no/index.php/techneA/article/view/3025

Räisänen, K. (May 17, 2017). Töitä olisi heti 9000 osaavalle koodarille, mutta tekijöitä ei löydy. [There would be jobs for 9,000 skilled coders right away, but no workers can be found]. Helsingin Sanomat. Retrieved from https://www.hs.fi/talous/art-2000005225501.html

Rönnerman, K. (2012). Aktionsforskning i praktiken - förskola och skola på vetenskaplig grund. [Action research in practice - preschool and school on a scientific basis]. Lund: Studentlitteratur.

Rosenfeld Halverson, E. \& Sheridan, K. (2014). The maker movement in education. Harvard Educational Review, 84(4), 495-504. https://doi.org/10.17763/haer.84.4.34j1g68140382063

Stukát, S. (2011). Att skriva examensarbete inom utbildningsvetenskap. [To write a degree project in educational science]. Lund: Studentlitteratur.

Sundqvist, E. (2016). Programmera mera i slöjden, en aktionsforskning om införandet av programmering $i$ slöjdundervisningen. [Programming in craft, an action research on the introduction of programming in craft education]. Unpublished Master's thesis in sloyd education. Vasa: Åbo Akademi.

Tapaninen, R. (Ed.), (2002). Peruskoulun käsityön opetustilojen suunnitteluopas. [Elementary school craft teaching facilities design guide]. Retrieved from https://www.oph.fi/download/137304_peruskoulun_kasityon_opetustilojen_suunnitteluopas.pdf

Uljas, M. \& Wendelius, S. (2018). Tää yhteinen käsityö on mitä suurimmassa määrin tilakysymys. [This common craft is, to the greatest extent, a matter of space]. Unpublished Master's thesis. Retrieved from https://www.utupub.fi/bitstream/handle/10024/146456/Uljas_Miika_Wendelius_Sara_opinnayte.pdf?sequenc $\underline{\mathrm{e}=1 \text { \&isAllowed }=\mathrm{y}}$

Rasmus Borg, MA in science of sloyd (craft) education, Åbo Akademi University, Finland. Customer Success Lead \& Pedagogic Specialist at 3DBear.

Mia Porko-Hudd, PhD, professor of science of sloyd (craft) education, Åbo Akademi University, Finland.

Juha Hartvik, $\mathrm{PhD}$, university lecturer in science of sloyd (craft) education, Åbo Akademi University, Finland. 